\title{
Myelodysplastic syndrome/acute myeloid leukemia evolving from aplastic anemia: Efficacy of hematopoietic stem cell transplantation
}

\author{
Irina K. Golubovskaya, Alexander D. Kulagin, Yulia V. Rudnitskaya, Elena V. Morozova, Anna A.Osipova, \\ Varvara N. Ovechkina, Nikolay Y. Tcvetkov, Sergey N.Bondarenko, *Boris I. Smirnov, Ludmila S. Zubarovskaya, \\ Inna V. Markova, Boris V. Afanasyev \\ R. Gorbacheva Memorial Institute of Children Oncology, Hematology and Transplantation, Chair of Hematology, Transfusiolo- \\ gy and Transplantology at The First St. Petersburg State I. Pavlov Medical University \\ ${ }^{\star}$ St. Petersburg State Electrotechnical University «LETI», St. Petersburg, Russia
}

Dr. Golubovskaya Irina Konstantinovna, First State Pavlov Medical University of Saint-Petersburg, Raisa Gorbacheva Memorial Research Institute for Pediatric Oncology,

Hematology and Transplantation Russia, Saint Petersburg, Lev Tolstoy str., 6/8.
Phone: +7 (921) 7852624 (mob.); +7 (812) 3386236 (office) E-mail: dr.irinagolubovskaya@gmail.com

\section{Summary}

Aplastic anemia (AA) is the most common clinical form of bone marrow failure which is still considered as a non-malignant disorder. However, development secondary myelodysplastic syndrome and acute myeloid leukemia (MDS/AML) in long-term AA survivors is confirmed by numerous studies. Treatment of the patients with secondary MDS/AML remains unresolved problem. The aim of present study was to evaluate efficacy of allogeneic hematopoietic stem cell transplantation (allo-HSCT) in secondary MDS/AML evolving from AA, and to determine the factors influencing clinical outcomes. The study included 26 patients with MDS/AML, previously treated with immunosuppressive treatment due to acquired AA. Median age was 25 (range, 9-45) years at the moment of MDS/AML diagnosis. Eight patients who had no available compatible donors, received chemotherapy alone, 18 patients received allo-HSCT (from matched related donor $(n=6)$, matched unrelated donor $(n=9)$, haploidentical donor $(n=3))$. Groups were comparable in pre-transplant characteristics of patients.
The 2-year overall survival (OS) in the chemotherapy alone group was $0 \%$, being $53.1 \%$ in HSCT group [ $(95 \%$ CI 41-65.2), $\mathrm{p}=0.024]$. For the patients being in remission state at the time of allo-HSCT, the 4-year OS comprised $80 \%$ [(95\% CI, 65-95), $\mathrm{p}=0.021]$ vs $27 \%$ in non-remission group. The use of peripheral blood as a source of graft was associated with higher OS $(p=0.014)$. Allo-HSCT remains the only potentially curative method for treatment of secondary MDS/AML from AA and should be performed as soon as possible in the case of registered evolution of AA to MDS/AML. Remission state at the time of allo-HSCT is the main predictor for a successful transplantation.

\section{Keywords}

Aplastic anemia, myelodysplastic syndrome, acute myeloid leukemia, hematopoietic stem cell transplantation. 


\section{Introduction}

Aplastic anemia (AA) is the most common clinical form of bone marrow failure which is still considered as a non-malignant disorder. However, W. Dameshek (1967) has noticed that severe AA may transform into paroxysmal nocturnal hemoglobinuria (PNH), secondary myelodysplastic syndrome (MDS) and acute myeloid leukemia (AML) [1]. At the present time, this dependence is confirmed by numerous studies [2-15]. Moreover, recent data show high incidence up to 50\% somatic mutations in patients with acquired AA, involving genes commonly mutated in myeloid malignancies [4].

Previously, most patients died within a year after primary diagnosis of SAA, until 1980's when implementation of antithymocyte globulin (ATG) combined with cyclosporin A (CsA) proved to be an effective immunosuppressive therapy (IST). Therefore, secondary clonal disorders in AA have become more common, due to longer survival of the patients. From 10 to $30 \%$ of AA patients treated with IST were shown to develop secondary clonal diseases, i.e., MDS/AML or $\mathrm{PNH}$, with a cumulative risk of 8 to $18 \%$ within next 10 years $[2-6,7,8,14]$. The patients with secondary disorders have worse prognosis than de novo AML or MDS cases, with a median survival of $<1$ year $[11,12,13]$. Diagnosis of NSAA, shorter telomere length, splenectomy, two or more ATG courses is related to increase risk for subsequent clonal complications $[2,6,9,10,15,16]$. By contrary, allogeneic bone marrow transplantation aimed for AA treatment causes a sufficiently reduced risk of such secondary disorders [11].

Therapeutic experience for these patients is limited, due to their rarity in common hematological practice. Clinical remissions achieved in such patients usually short and accompanied by high minimal residual disease levels. Moreover, these patients poorly tolerate chemotherapy; they develop longer cytopenia and often die from complications. Allogeneic hematopoietic stem cell transplantation (allo-HSCT) remains the only potentially curative method for these conditions. The aim of present study was to evaluate efficiency of allo-HSCT in secondary MDS/AML evolving from AA, and to determine the factors influencing clinical outcomes.

\section{Patients and methods}

The retrospective study included 26 patients with MDS/ AML, previously treated with IST due to acquired AA. The patients were observed in First St. Petersburg State I. Pavlov Medical University and Novosibirsk Institute of Clinical Immunology from July 1998 to June 2018. The survival assessment was completed at 15.06.2018.

Acquired AA was diagnosed according to standard criteria (International Agranulocytosis and Aplastic Anemia Study Group, 1987). The AA severity grade was evaluated by common criteria $[17,18]$. The degree of response corresponded to standard definitions [19]. Fanconi anemia and other inherited AA were not included into the study.

Majority of patients (19/26), received as a combination of ATG and CsA, six patients received CsA as monotherapy. Splenectomy has been performed in other centers in seven cases.
The patients were observed for a median of 6 years (range, 0.9 to 33 ) from the AA diagnosis. Sixteen patients were enrolled into the study group at the stage of clonal disorders. The median age at the time of AA diagnosis was 17 (range, 5 to 41 ) and 25 (range, 9 to 45 ) years at MDS/AML transformation, respectively.

MDS transformation was diagnosed by characteristic morphological changes in bone marrow, increasing blast cell numbers, and typical chromosome aberrations (International Working Group on Morphology of Myelodysplastic Syndrome, 2008). Clinical MDS variant was determined according to the WHO classification (WHO classification of the myeloid neoplasms, 2016). AML was diagnosed when the ratio of blast cells in bone marrow exceeded $20 \%$. The AML phenotype was determined by means of morphological, cytochemical, immunophenotyping assays, as well as cytogenetic methods and molecular markers.

Eight patients were treated with chemotherapy and/or hypomethylating treatment. All the patients provided informed consent for the use of their medical data for research purposes, according to the Helsinki Declaration. Eighteen patients received allo-HSCT, either from matched related donor (MRD) $(n=6)$, matched unrelated donor (MUD) $(n=9)$ or haploidentical donor $(n=3)$. Most patients underwent the non-myeloablative conditioning regimen consisting of fludarabine $180 \mathrm{mg} / \mathrm{m}^{2}$ and busulfan $10 \mathrm{mg} / \mathrm{kg}(\mathrm{n}=14)$. Graft-versus-host disease (GVHD) prophylaxis included the combination tacrolimus ( $\mathrm{Tx}$ ) and mycophenolate mofetil (MMF) (n=6), CsA/methotrexate combined therapy $(n=6)$ and post-transplant cyclophosphamide (PtCy) at a dose of $50 \mathrm{mg} / \mathrm{kg}$ on $\mathrm{D}+3, \mathrm{D}+4(\mathrm{n}=6)$.

Engraftment criteria were absolute neutrophil counts of $>0.5 \times 10^{9} / \mathrm{L}$ for 3 subsequent days and platelet numbers to $>20 \times 10^{9} / \mathrm{L}$ in absence of preceding platelet transfusions for 7 days. The GvHD severity and grade were assessed according to Przepiorka D. et al., 1995 [20].

Clinical relapse was diagnosed upon hematological recurrence of MDS or AML signs.

The overall survival parameters were evaluated by Kaplan-Meier approach, calculating the confidence interval values (CI 95\%) using a log-rank test for evaluation of differences between the survival curves. Descriptive inter-group differences were evaluated with exact Fisher criterion for categorical characteristics, and Mann-Whitney U test (for 2 groups) and Kruskal-Wallis criterion ( $>2$ groups). Univariate and multivariate survival analyses were carried out using the Cox proportional hazard model. All significant variables among those assessed in univariate analysis were considered for the multivariate model. The STATISTICA 10.0 (StatSoft Inc., USA) software was used.

\section{Results}

\section{Clinical characteristics}

A total of 26 patients were included, male/female 15/11, with median age of 25 years at the moment of MDS/AML diagnosis. More than a half of patients $(n=14)$ had the history of 
non-severe AA (NSAA). Cytogenetic study was performed in twelve cases upon primary diagnostics, showing normal karyotype in all cases. The PNH clone was tested in 17 patients as a part of AA diagnostics, and a minor PNH clone was revealed in 7 cases. Moreover, three patients with partial AA remission showed signs of hemolytic PNH (resp., 4, 6 and 14 years after the debut), with subsequent $\mathrm{PNH}$ clone disappearance and evolution to MDS/AML, respectively, 10, 13 and 22 years later. In 7 out of 26 patients, even partial AA remission was achieved. The most common cytogenetic abnormality was monosomy 7 .

The demographic and clinical characteristics of the patients are presented in Table 1.

\section{Treatment results}

Eight patients with secondary AML who had no available compatible donors, received chemotherapy: «7+3» $(n=3)$, low-dose cytarabine $(n=2)$, FLAG $(n=1)$ and high-dose cytarabine $(n=2)$. MDS patients were treated with 5-azacytidine or low-dose cytarabine. All patients initially diagnosed with MDS developed AML within 24 months. All patients treated by chemotherapy/hypomethylating agents alone $(n=8)$, died with median survival time of 6 ( 1 to 25$)$ months since the malignant transformation. They all were scheduled for unrelated HSCT which, however, could not be timely performed. Among the patients subjected to allo-HSCT $(n=18)$, eight patients are still alive, at a median follow-up time of 4.8 years ( 0.5 to 12 years). The 2 -year overall survival (OS) in the chemotherapy alone group was $0 \%$, being $53.1 \%$ in HSCT group [(95\% CI 41-65.2), $\mathrm{p}=0.024]$ as shown in Fig. 1.

\section{Allo-HSCT for secondary MDS/AML}

A total of 26 allo-HSCTs were performed in 18 patients. Median age at the HSCT was 23 (11-44) years. The median time from MDS/AML diagnosis to HSCT was 7 (2 to 18) months. For the first HSCT, HLA-identical siblings were used for 6 patients (33\%), a MUD in 9 (50\%) of cases, whereas haploidentical familial donor was used for three patients (17\%). Repeated HSCT was in most cases performed from haploidentical donors $(n=5)$. Before allo-HSCT, eight patients received hypomethylating agents (5-azacytidine, decitabine). Four of six patients achieved first complete remission after «7+3» chemotherapy. One patient was treated at low-dose cytarabine and 3 patients with myelodysplastic syndrome

Table 1. Characteristics of the patients with AA transformed to MDS/AML

\begin{tabular}{|c|c|c|c|}
\hline Patients & $\begin{array}{l}\text { Total } \\
(\mathrm{n}=26)\end{array}$ & HSCT (n=18) & Chemotherapy ( $\mathrm{n}=8$ ) \\
\hline $\begin{array}{l}\text { Gender, } \mathrm{n}(\%) \\
\text { Male } \\
\text { Female }\end{array}$ & $\begin{array}{l}15(58) \\
11(42) \\
\end{array}$ & $\begin{array}{l}11(61) \\
7(39)\end{array}$ & $\begin{array}{l}4(50) \\
4(50)\end{array}$ \\
\hline Age at AA diagnosis, years, median (range) & $17(5-41)$ & $20(8-34)$ & $16(5-41)$ \\
\hline $\begin{array}{l}\text { Time interval from the AA to the AML/MDS } \\
\text { transformation, years, median (range) }\end{array}$ & $6,4(0,9-33)$ & $5,6(0,9-22)$ & $9(1-33)$ \\
\hline $\begin{array}{l}\text { AA severity, n (\%) } \\
\text { NSAA } \\
\text { SAA } \\
\text { VSAA }\end{array}$ & $\begin{array}{l}14(54) \\
10(38) \\
2(8)\end{array}$ & $\begin{array}{l}11(61) \\
7(39) \\
0\end{array}$ & $\begin{array}{l}3(37,5) \\
3(37,5) \\
2(25)\end{array}$ \\
\hline $\begin{array}{l}\text { Initial AA treatment, } \mathrm{n}(\%) \\
\text { ATG+CsA } \\
\text { CsA monotherapy } \\
\text { Splenectomy +/- CsA, ATG }\end{array}$ & $\begin{array}{l}16(62) \\
3(11) \\
7(27)\end{array}$ & $\begin{array}{l}11(61) \\
2(11) \\
5(28)\end{array}$ & $\begin{array}{l}5(63) \\
1(12) \\
2(25)\end{array}$ \\
\hline $\begin{array}{l}\text { Efficacy of AA therapy, } n \text { (\%) } \\
\text { Complete and partial response } \\
\text { No response/minimal hematological response }\end{array}$ & $\begin{array}{l}16(62) \\
10(38)\end{array}$ & $\begin{array}{l}10(56) \\
8(44)\end{array}$ & $\begin{array}{l}6(75) \\
2(15)\end{array}$ \\
\hline PNH clone (n=17) +/-, n (\%)/n (\%) & $7 / 9$ & $5 / 7$ & $2 / 3$ \\
\hline $\begin{array}{l}\text { Diagnosis at HSCT/ChT, n (\%) } \\
\text { AML } \\
\text { MDS-EB-1 and MDS-EB-2 } \\
\text { MDS-MLD } \\
\text { CMML }\end{array}$ & $\begin{array}{l}11(42) \\
10(38) \\
3(12) \\
2(8) \\
\end{array}$ & $\begin{array}{l}6(33) \\
8(44) \\
3(17) \\
1(6) \\
\end{array}$ & $\begin{array}{l}5(63) \\
2(25) \\
0 \\
1(12) \\
\end{array}$ \\
\hline $\begin{array}{l}\text { Karyotype }(\mathrm{n}=25), \mathrm{n}(\%) \\
\text { Monosomy } 7 \\
\text { Trisomy } 8 \\
\text { Normal karyotype } \\
\text { Hyperdiploidy and complex aberrations }\end{array}$ & $\begin{array}{l}18(72) \\
1(4) \\
2(8) \\
4(16)\end{array}$ & $\begin{array}{l}\mathrm{n}=18 \\
12(67) \\
1(6) \\
2(11) \\
3(16)\end{array}$ & $\begin{array}{l}n=7 \\
6(86) \\
0 \\
0 \\
1(14)\end{array}$ \\
\hline
\end{tabular}




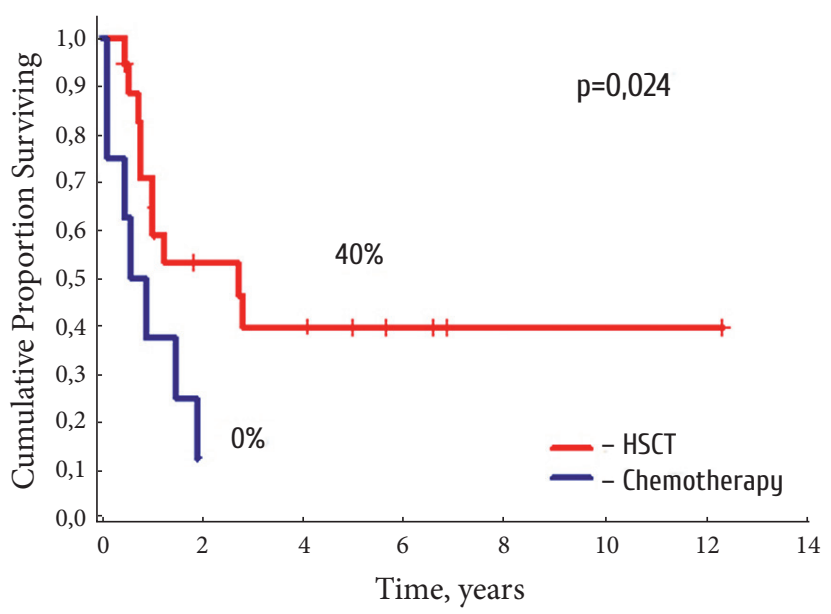

Figure 1. Overall survival rates after allo-HSCT and chemotherapy

with multilineage dysplasia (MDS-MLD), received only supportive care. All the patients had multiple transfusions of RBC and platelets in their past history. The median of ferritin level at the time of HSCT was 1430 (205-10500) ng/mL.

Biological and clinical characteristics of transplanted patients and HSCT procedure are presented in Table 2.

Successful engraftment was documented in 12 patients, with a median at $\mathrm{D}+16(\mathrm{D}+12$ to $\mathrm{D}+25)$, platelet recovery, at $\mathrm{D}+17(\mathrm{D}+11$ to $\mathrm{D}+20)$. Seven patients (39\%) developed acute GVHD grade II-IV, resulted in death in 2 cases. All the HSCT survivors have clinical signs of moderate or severe chronic GVHD.

Primary graft failure was registered in six patients (33\%): 3 after haploidentical, 2 after unrelated and 2 after related HSCT. A secondary graft rejection was revealed in 2 patients after unrelated HSCT. Two patients developed relapse of MDS/AML.

Seven patients with primary graft failure/graft rejection were subjected to repeated HSCT from haploidentical donor $(n=5)$, related $(n=1)$, or unrelated donors $(n=1)$. However, the engraftment after repeated HSCT was not achieved in 5 cases, patients died in cytopenia from hemorrhagic and infectious complications. One patient after repeated MUD HSCT developed a fatal GVHD grade IV. Two patients developed the disease relapse (respectively, D+56 after related HSCT in 2 cases, and D+380 after unrelated HSCT). The causes of post-transplant mortality are presented in Table 3.

Seven transplanted patients have got hypomethylating drugs at a mean of 6 courses (5-azacytidine, in 4 cases; decitabine in 3 patients) aiming to prevent relapses.

\section{Analysis of prognostic factors}

Assessment of prognostic significance for distinct biological and clinical parameters is presented in Table 4.

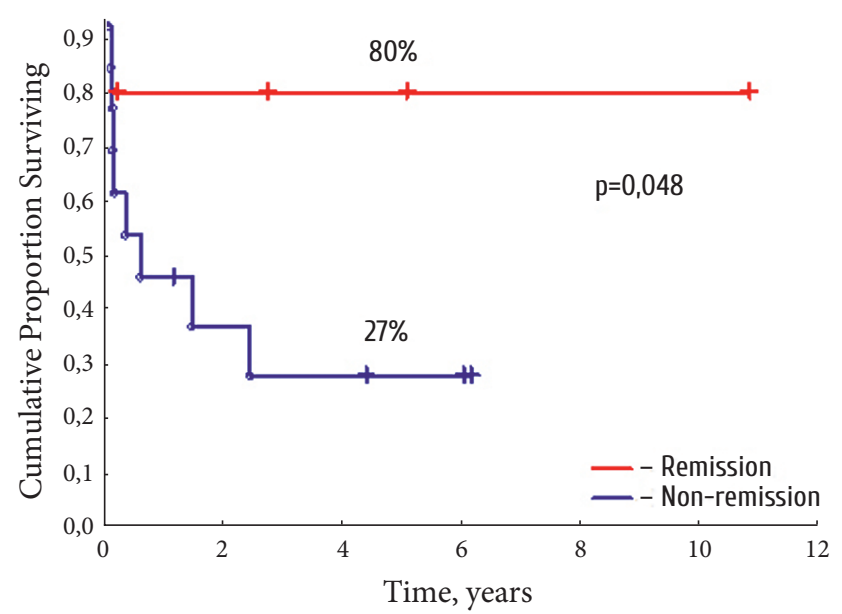

Figure 2. Overall survival (OS) in secondary MDS/AML depends on the primary disease state (remission vs beyond remission before HSCT)

According to further statistical evaluation, such factors as patient's gender, age, conditioning regimen, GVHD prophylaxis, CMV status, ABO mismatch, numbers of CD34+ and mononuclear cells did not have a significant effect on overall survival $(p>0,1)$. The use of peripheral blood as a source of graft was associated with higher overall survival $(p=0.014)$. The overall post-transplant survival proved to be significantly dependent only on remission state at the time of HSCT (Fig. 2).

HSCT timing seems to be important in patients with MDSMLD. Of the three patients only one survived, who received hematopoietic graft 2 months after the MDS diagnosis (monosomy 7, marrow dysplasia). Two deceased patients were transplanted much later, $>1$ year after the diagnosis, when the patients continued to receive replacement transfusions. High ferritin levels did not significantly impair survival. Of note, the transfusion load for these patients was quite significant (median RBC transfusions 23 units; platelets, 44 units by the time of HSCT).

\section{Discussion}

Treatment of the patients with secondary MDS/AML remains unresolved problem, and its results are worse to those in primary patients. Especially, one should consider high rates of severe cytopenia-associated complications after standard therapy of the patients with previously diagnosed AA, probably, due to reduced regenerative ability of bone marrow. In most patients, unstable clinical remission could be obtained after chemotherapy, with high levels of minimal residual disease. In some patients remission is not achieved, or they die from hemorrhagic and infectious complications after 1st induction course. Meanwhile, with increased life duration of IST-treated AA patients, the number of patients with secondary MDS/AML will increase. Therefore, novel algorithm is required for management of such patients. 
Table 2. Transplant and patients characteristics

\begin{tabular}{|c|c|}
\hline Characteristics & $\mathrm{N}=18$ \\
\hline $\begin{array}{l}\text { Gender, n (\%) } \\
\text { Male } \\
\text { Female }\end{array}$ & $\begin{array}{l}11(61) \\
7(39)\end{array}$ \\
\hline Age at $\mathrm{HSCT}$, years, median (range) & $23(11-44)$ \\
\hline $\begin{array}{l}\text { Diagnosis at HSCT, } n(\%) \\
\text { AML } \\
\text { CMML } \\
\text { MDS-EB-1 and MDS-EB-2 } \\
\text { MDS-MLD }\end{array}$ & $\begin{array}{l}6(33) \\
1(6) \\
8(44) \\
3(17)\end{array}$ \\
\hline $\begin{array}{l}\text { Treatment before HSCT, } \mathrm{n}(\%) \\
\text { Chemotherapy+/-hypomethylating agents } \\
\text { Only hypomethylating agents } \\
\text { Supportive care }\end{array}$ & $\begin{array}{l}8(44) \\
7(39) \\
3(17)\end{array}$ \\
\hline $\begin{array}{l}\text { Disease state at the HSCT, n (\%) } \\
\text { Relapse/Refractory disease } \\
\text { Remission (complete/partial) }\end{array}$ & $\begin{array}{l}11(61) \\
7(39)\end{array}$ \\
\hline Time interval between AML/MDS diagnosis and HSCT, months, median (range) & $7(2-18)$ \\
\hline Ferritin level, ng/ml, median (range) & $1430(205-10300)$ \\
\hline Platelet units pre-transplant, median, (range) & $44(10-210)$ \\
\hline RBC units pre-transplant, median, (range) & $23(3-113)$ \\
\hline $\begin{array}{l}\text { Donor type, n (\%) } \\
\text { Related } \\
\text { Unrelated } \\
\text { Haploidentical }\end{array}$ & $\begin{array}{l}6(33) \\
9(50) \\
3(17)\end{array}$ \\
\hline $\begin{array}{l}\text { Source of transplant, } \mathrm{n}(\%) \\
\text { Bone marrow } \\
\text { Peripheral blood } \\
\text { Bone marrow+ Peripheral blood }\end{array}$ & $\begin{array}{l}9(50) \\
8(44) \\
1(6)\end{array}$ \\
\hline $\begin{array}{l}\text { Gender combinations donor-recipient, n (\%) } \\
\text { Female-Male } \\
\text { Female-Female } \\
\text { Male-Female } \\
\text { Male-Male }\end{array}$ & $\begin{array}{l}5(28) \\
4(22) \\
3(17) \\
6(33)\end{array}$ \\
\hline $\begin{array}{l}\text { CMV donor state, } \mathrm{n}(\%) \\
\text { Positive } \\
\text { Negative }\end{array}$ & $\begin{array}{l}11(61) \\
7(39)\end{array}$ \\
\hline $\begin{array}{l}\text { AB0 incompatibility, } n(\%) \\
\text { Compatibility } \\
\text { Minor } \\
\text { Major }\end{array}$ & $\begin{array}{l}11(61) \\
4(22) \\
3(17)\end{array}$ \\
\hline Nucleated cells x 108/kg, median, (range) & $3,85(1,1-10,8)$ \\
\hline Number of CD34+ cells x 106/kg, median, (range) & $4(1-9)$ \\
\hline
\end{tabular}


Table 3. Causes of death in the patients after allo-HSCT, dependent on a donor type

\begin{tabular}{|c|c|c|c|c|c|}
\hline \multirow[t]{3}{*}{ Donor types } & \multirow{3}{*}{$\begin{array}{l}\text { Lethal outcome } \\
\text { (n)/total } \\
\text { case number (n) }\end{array}$} & \multicolumn{4}{|c|}{ Causes of death, number of patients, $n$ (\%) } \\
\hline & & \multicolumn{2}{|c|}{ Cytopenia-associated complications } & \multirow{2}{*}{$\begin{array}{l}\text { Acute GVHD } \\
\text { grade IV }\end{array}$} & \multirow{2}{*}{$\begin{array}{l}\text { Leukemic } \\
\text { relapse }\end{array}$} \\
\hline & & Non-engraftment & Graft rejection & & \\
\hline HLA-identical sibling & $3 / 6$ & $1 / 3$ & $0 / 3$ & $1 / 3$ & $1 / 3$ \\
\hline Unrelated donor & $5 / 7$ & $2 / 7$ & $1 / 7$ & $1 / 7$ & $1 / 7$ \\
\hline Haploidentical donor & $2 / 3$ & $2 / 3$ & $0 / 3$ & $0 / 3$ & $0 / 3$ \\
\hline
\end{tabular}

Table 4. Factors, influencing overall survival values in HSCT (Cox regression method)

\begin{tabular}{|c|c|c|c|c|c|c|}
\hline \multirow[t]{2}{*}{ Factor } & \multicolumn{3}{|c|}{ Univariate analysis } & \multicolumn{3}{|c|}{ Multivariate analysis } \\
\hline & RR & Cl 95\% & $\mathrm{p}$-value & RR & Cl 95\% & $\mathrm{p}$-value \\
\hline \multicolumn{7}{|c|}{ Disease status } \\
\hline Remission & \multicolumn{3}{|l|}{1} & \multicolumn{3}{|l|}{1} \\
\hline Non-remission & 6,67 & $1,17-53,1$ & 0,048 & 25,7 & $1,62-107,8$ & 0,021 \\
\hline \multicolumn{7}{|c|}{ Source of transplant } \\
\hline Peripheral blood & \multicolumn{3}{|l|}{1} & \multicolumn{3}{|l|}{1} \\
\hline Bone marrow & 4,8 & $1,07-22,6$ & 0,049 & 11,2 & $1,6-77$ & 0,014 \\
\hline \multicolumn{7}{|c|}{ Donor type } \\
\hline Matched related donor & \multicolumn{3}{|l|}{1} & \multicolumn{3}{|l|}{1} \\
\hline 0thers & 1,76 & $1,09-8,38$ & 0,047 & 7,8 & $0,74-82,6$ & 0,09 \\
\hline \multicolumn{7}{|c|}{ Gender (recipient) } \\
\hline Male & \multicolumn{3}{|l|}{1} & \multicolumn{3}{|l|}{1} \\
\hline Female & 3,08 & $0,84-17,7$ & 0,092 & 5,7 & $0,9-82,1$ & 0,627 \\
\hline
\end{tabular}

In our study, all the non-transplanted patients have developed acute leukemia within 2 years since the MDS diagnosis. Overall 4-year survival of the patients subjected to HSCT was $40 \%$ (95\% CI, 38-52) compared to zero survival among non-transplanted patients. For the patients being in remission state at the time of HSCT, the 4-year OS comprised $80 \%$ (95\% CI, 65-95), thus being in accordance with results presented by European Bone Marrow Transplantation Group [21]. Our study has confirmed that allogeneic HSCT is the only option able to cure the patient with secondary MDS/ AML evolving after AA. The time interval from diagnosis of secondary disorder to HSCT is the critical factor for success, due to rapid transformation of MDS to AML, poor chemotherapy tolerance, and high risk of lethal outcome before HSCT.

To provide HSCT within short terms for these patients, it is necessary to perform HLA typing of the patients at the stage of AA, in order to assess availability of potential donors (for NSAA patients as well), regular examination after IST, including cytogenetic studies of bone marrow, especially, in resistant and relapsing AA conditions. It was shown that the probability of arising pathological clones with chromosom- al aberrations makes up to $40 \%$ in non-responders to IST, in $6 \%$ with partial response, and in $10 \%$ of patients well responding to the treatment.

Risk for clonal disorders in the patients non-responding to IST, and in cases of preceding NSAA sufficiently exceeds appropriate hazards in the patients with partial response, full response to the therapy, and severe AA $[8,9,10]$.

Our study, though performed in a small group, has detected a significantly increased OS in the patients subjected to allo-HSCT, as compared to the patients who received chemotherapy only ( $40 \%$ among transplanted patients versus $0 \%$ in the non-transplanted cases), thus again stressing the role of remission state as the main factor of favorable prognosis in HSCT series. Prognostic significance of remission state was confirmed in our multifactorial analysis. However, one may suppose that, when increasing the number of patients, this factor will significantly influence the results as it was shown in other studies dealing with greater cohorts [21]. Moreover, we have noted a tendency towards better HSCT outcomes in the persons $<21$ years old, as well as when using the mobilized hematopoietic stem cells as a source of graft. The type 
of conditioning regimen also did not have significant impact on the HSCT results, but some studies declare benefits of myeloablative conditioning for treatment of secondary MDS $[21,23]$. In our study, only 3 out of 16 patients were subjected to myeloablative conditioning, with engraftment in 2 of 3 cases. However, the most patients were admitted to the BMT Center after prolonged conservative therapy, and their comorbid state did not allow to performing myeloablative conditioning.

Frequency of aGVHD in total was $27 \%$, severe aGVHD (grade III-IV) was 19\% and caused lethal outcome in two cases. Chronic GVHD of different grade was observed in all survivors; however, it did not result into severe disability.

According to our data, primary graft failure is the most common cause for HSCT failure (33\% of total group in our study). This is a significantly higher incidence compared with data reported by other authors [21, 23]. To our mind, heavy pre-treatment, multiple blood transfusions, as well as numerous courses of chemotherapy and demethylating treatment predisposing for infections, may cause this post-transplant complication.

It is difficult to determine efficiency of haploidentical HSCT in this study because of few clinical cases $(n=3)$, however, primary non-engraftment seems to be the main problem in this HSCT option.

Carrying out repeated HSCTs following primary non-engraftment allowed achieving hematopoietic recovery in two cases $(25 \%)$, with one lethal outcome due to grade IV aGVHD.

Therapy with hypomethylating drugs during the post-transplant period is used to prevent and treat relapses in the patients with high risk AML [24]. Our study has shown promising results of such strategy in cases of secondary MDS/ AML as well.

\section{Conclusions}

Allogeneic hematopoietic stem cell transplantation is the only potentially curative method for treatment of MDS/ AML occurring in the patients previously treated with immunosuppressive therapy for AA.

Remission state at the time of HSCT is the main predictor for a successful transplantation. Using peripheral blood as a source of graft improves overall survival in patients with secondary MDS/AML from AA. Allo-HSCT is indicated as soon as possible in the case of registered evolution of AA to MDS/AML.

\section{Conflict of interest}

No conflicts of interests are reported.

\section{References}

1. Dameshek W. Riddle: what do aplastic anemia, paroxysmal nocturnal hemoglobinuria (PNH) and «hypoplastic» leukemia have in common? Blood 1967;30(2):251-254.
2. Tichelli A, Gratwohl A, Nissen C, Speck B. Late clonal complications in severe aplastic anemia. Leuk Lymphoma 1994;12 (3-4):167-175.

3. Ohara A, Kojima S, Hamajima N, Tsuchida M, Imashuku S, Ohta S, Sasaki H, Okamura J, Sugita K, Kigasawa H, Kiriyama Y, Akatsuka J, Tsukimoto I. Myelodysplastic syndrome and acute myelogenous leukemia as a late clonal complication in children with acquired aplastic anemia. Blood 1997; 90(3):1009-1013.

4. Ogawa S. Clonal hematopoiesis in acquired aplastic anemia. Blood. 2016;128(3):337-347.

5. Kojima S, Ohara A, Tsuchida M, Kudoh T. Hanada R, Okimoto Y, Kaneko T, Takano T, Ikuta K, Tsukimoto I. Risk factors for evolution of acquired aplastic anemia into myelodysplastic syndrome and acute myeloid leukemia after immunosuppressive therapy in children. Blood 2002;100(3):786790.

6. Socie G, Henry-Amar M, Bacigalupo A, Hows J, Tichelli A, Ljungman P, McCann SR, Frickhofen N, Van't Veer-Korthof E, Gluckman E. European Bone Marrow Transplantation Severe Aplastic Anemia Working Party: Malignant tumors occurring after treatment of aplastic anemia. N Engl J Med. 1993;329(16):1152-1157.

7. Afable M, Tiu R, Maciejewski J. Clonal evolution in aplastic anemia. Hematology Am Soc Hematol Educ Program. 2011;2011:90-95.

8. Kulagin AD, Lisukov IA, Kozlov VA. Aplastic anemia: immune pathogenesis, clinical features, diagnostics, treatment. 2008; Novosibirsk: Nauka Publ. 236 p (In Russian).

9. Kulagin AD. Clinical, hematological and immunological criteria for long-term prognosis of acquired aplastic anemia. Doctor'sThesis: 1st St.Petersburg State I.Pavlov Medical University, St.Petersburg, 2015 (In Russian).

10. Kulagin A, Borisov V, Pronkina N, Kruchkova I, Lisukov I, Afanasyev B. Long-term outcomes of accelerated telomere shortening in acquired aplastic anemia. Blood. 2014;124(21):4396.

11. Golubovskaya IK, Ganapiev AA, Kulagin AD, Bondarenko SN, Stancheva NV, Vavilov VV, Lisukov IA, Afanasyev BV. Myelodysplastic syndrome and acute myeloid leukemia (MDS/AML) in long-term survivors of aplastic anemia. Cell Ther Transplant. 2010; 3(3): 44.

12. Borthakur G, Estey A. Therapy-related acute myelogenous leukemia and myelodysplastic syndrome. Curr Oncol Rep. 2007;9(5):373-377.

13. Armand P, Kim H, DeAngelo DJ, Ho VT, Cutler CS, Stone RM, Ritz J, Alyea EP, Antin JH, Soiffer RJ. Impact of cytogenetics on outcome of de novo and therapy-related AML and MDS after allogeneic transplantation. Biol Blood Marrow Transplant 2007; 13(6):655-664.

14. Kulagin A, Golubovskaya I, Ivanova M, Babenko E, Pronkina N, Kruchkova I, Lisukov I, Afanasyev B. Incidence and risk factors for hemolytic paroxysmal nocturnal hemoglobinuria $(\mathrm{PNH})$ in aplastic anemia (AA) patients. Bone Marrow Transplant. 2014;49 (Suppl 1):S42-43. 
15. Frickhofen N, Heimpel H, Kaltwasser JP, Schrezenmeier H. Antithymocyte globulin with or without cyclosporin A: 11-year follow-up of a randomized trial comparing treatments of aplastic anemia. Blood 2003;101(4):1236-1242.

16. Scheinberg P, Cooper JN, Sloand EM, Wu CO, Calado RT, Young NS. Association of telomere length of peripheral blood leukocytes with hematopoietic relapse, malignant transformation, and survival in severe aplastic anemia. JAMA. 2010; 304(12):1358-1364.

17. Camitta B, Thomas E, Nathan DG, Santos G, Gordon-Smith EC, Gale RP, Rappeport JM, Storb R. Severe aplastic anemia: a prospective study of the effect of early marrow transplantation on acute mortality. Blood 1976;48(1):63-70.

18. Bacigalupo A, Hows J, Gluckman E. Bone marrow transplantation (BMT) versus immunosuppression for the treatment of severe aplastic anaemia (SAA): a report of the EBMT SAA working party. Br J Haematol. 1988;70(2):177-182.

19. Camitta B. What is the definition of cure for aplastic anemia? Acta Haematol. 2000;103(1):16-18.

20. Przepiorka D, Weisdorf D, Martin P, Klingemann HG, Beatty P, Hows J, Thomas ED. Consensus conference on acute GVHD grading. Bone Marrow Transplant 1995;15(6):825828 .

21. Kröger N, Iacobelli S, Franke GN, Platzbecker U, Uddin R, Hübel K, Scheid C, Weber T, Robin M, Stelljes M, Afanasyev B, Heim D, Deliliers GL, Onida F, Dreger P, Pini M, Guidi S, Volin L, Günther A, Bethge W, Poiré X, Kobbe G, van Os $\mathrm{M}$, Brand $\mathrm{R}$, de Witte T. Dose-reduced versus standard conditioning followed by allogeneic stem-cell transplantation for patients with myelodysplastic syndrome: a prospective randomized Phase III Study of the EBMT (RICMAC Trial). J Clin Oncol. 2017;35(19):2157-2164.

22. Hussein AA, Halkes CM, Socié G, Tichelli A, von dem Borne PA, Schaap MN, Foa R, Ganser A, Dufour C, Bacigalupo A, Locasciulli A, Aljurf M, Peters C, Robin M, van Biezen A, Volin L, De Witte T, Marsh J, Passweg JR, Kröger $\mathrm{N}$. Outcome of allogeneic stem cell transplantation for patients transformed to myelodysplastic syndrome or leukemia from severe aplastic anemia: a report from the MDS Subcommittee of the Chronic Malignancies Working Party and the Severe Aplastic Anemia Working Party of the European Group for Blood and Marrow Transplantation. Biol Blood Marrow Transplant 2014;20(9):1448-1450.

23. Kim S, Le Rademacher J, Antin J, Anderlini P, Ayas M, Battiwalla M, Carreras J, Kurtzberg J, Nakamura R, Eapen M, Deeg HJ. Myelodysplastic syndrome evolving from aplastic anemia treated with immunosuppressive therapy: efficacy of hematopoietic stem cell transplantation. Haematologica. 2014;99(12):1868-1875.

24. Mawad R, Lionberger J, Pagel J. Strategies to reduce relapse after allogeneic hematopoietic cell transplantation in acute myeloid leukemia. Curr Hematol Malig Rep. 2013;8(2):132-140. 


\section{Миелодиспластический синдром и острый миело- бластный лейкоз, развивающиеся из апластической анемии: эффективность аллогенной трансплантации гемопоэтических стволовых клеток}

Ирина К. Голубовская, Александр Д. Кулагин, Юлия В. Рудницкая, Елена В. Морозова, Анна А. Осипова, Варвара Н. Овечкина, Николай Ю. Цветков, Сергей Н. Бондаренко, ^Борис И. Смирнов, Людмила С. Зубаровская, Инна В. Маркова, Борис В. Афанасьев

НИИ детской онкологии, гематологии и трансплантологии им. Р. Горбачевой; кафедра гематологии, трансфузиологии и трансплантологии Первый Санкт-Петербургский государственный медицинский университет им. И. П. Павлова *Санкт-Петербургский государственный электротехнический университет «ЛЭТИ», Санкт-Петербург, Россия

\section{Резюме}

Апластическая анемия (АА) наиболее частый встречаемый вариант костно-мозговой недостаточности, рассматриваемый как незлокачественное заболевание. Тем не менее, во многих исследованиях подтверждено развитие вторичного миелодиспластического синдрома и острого миелоидного лейкоза (МДС/ОМЛ) у долгоживущих пациентов с АА. Лечение пациентов с вторичным МДС/ОМЛ остается нерешенной проблемой. Целью данного исследования являлась оценка эффективности аллогенной трансплантации гемопоэтических стволовых клеток (алло-ТГСК) при развитии вторичного МДС/ ОМЛ из АА и выявление факторов, оказывающих влияние на клинические исходы лечения. В исследование было включено 26 пациентов с МДС/ОМЛ, ранее получавших иммуносупрессивную терапию в рамках лечения приобретенной АА. Медиана возраста на момент установления диагноза МДС/ОМЛ составила 25 лет (9-45). Восемь пациентов, не имевших доступного совместимого донора, получали только химиотерапию, 18 пациентов получили алло-ТГСК (от полностью совместимого родственного донора ( $\mathrm{n}=6)$, полностью совместимого неродственного донора $(\mathrm{n}=9)$, гаплоидентичного донора $(\mathrm{n}=3)$.
Двухлетняя общая выживаемость (OB) в группе пациентов, получавших только химиотерапию, составила 0 \% с равнение с 53,1\% ((95\% ДИ 41-65,2), $\mathrm{p}=0,024)$ ОВ в группе пациентов после алло-ТГСК. Для пациентов, получивших ТГСК в ремиссии заболевания ОВ, составляла 80\% ((95\% ДИ, 65-95), $\mathrm{p}=0,021)$ против $27 \%$ ОВ среди пациентов, не достигших ремиссии к моменту алло-ТГСК. Использование периферической крови в качестве источника трансплантата было ассоциировано с более высокой OB (p=0,014). Алло-ТГСК остается единственным потенциально излечивающим методом лечения для пациентов с вторичным МДС/ОМЛ из АА, и должна по возможности выполняться в самые кратчайшие сроки после констатации перехода АА в МДС/ОМЛ. Ремиссионный статус на момент алло-ТГСК является главным предиктором успешной трансплантации.

\section{Ключевые слова}

Апластическая анемия, миелодиспластический синдром, острый миелоидный лейкоз, трансплантация гемопоэтических стволовых клеток. 